\title{
The CNN Series on the Cold War: History as Narrative and Entertainment
}

No war in recent memory has raged as long and intensely as the Cold War, permeating western and eastern hemispheres, expressing itself in long bouts of propaganda warfare and ideological hostility and pushing the world to the brink of nuclear holocaust. At the same time, no war has proven to be as multifaceted, insidious and all encompassing as the Cold War, transcending not just geographical boundaries but also the ideological and economic confines of diverse systems, and reflecting the profound structural weaknesses of the major superpowers. Symptomatic of this complex and tortuous conflict is the fact that no simple consensus exists as to when the Cold War started, why and how it took shape, who was the major culprit, and what factors were most responsible for its emergence and persistence. In fact, the historiography of the Cold War is distinguished for its diversity of perspectives, its conflicting schools of thought, and its dynamic and provocative exchange of ideas between the traditional, orthodox school and the revisionist, New Left school. ${ }^{1}$

You would not be aware of these dynamics and of a more complex understanding of the Cold War if you depended solely on the recent CNN Cold War documentary series. For Ted Turner's production is big on chronology, historical narrative and description while weak on analytical depth. The series comes as a slick, multimedia package consisting of 24 television episodes, a coffee-table book, and an extensive web-site. However, these accessories give us technological glitz at the expense of historical understanding. The documentary offers the latest in packaging, combining suspenseful music with a rich and unique archival collection of newsreel and film material. Indeed, much of the footage, never seen before, reveals personal portraits and inner intricacies which enrich this documentary. Moreover, some of the recent interviews, by engaging in frank discussions with leaders like Fidel Castro or George Bush, or in conversation with "ordinary" people of countries like the former USSR or Italy - important witnesses to history - lend substance to the Cold War saga. To the extent that this documentary excels in providing a comprehensive, chronological narrative of the Cold War, it can be used effectively in the undergraduate classroom not just as a source of factual information, but also as a point of departure for analysis and interpretation. At this point, however, the documentary quickly reaches its limits, for it is also small on controversy, diversity, complexity of interpretation, historical analysis, and criticism. In effect, the overall picture one gains of the Cold War is that of a highly simplified and sometimes Manichean struggle between the US and the USSR, between 
good and evil, between the forces of democracy, in particular, American democracy, and those of communism, especially those most shaped by Stalin. With a couple of exceptions, it is as if American capitalism had little, if anything, to do with the Cold War, for the latter was primarily shaped by exaggerated responses of statesmen on both sides of the "iron curtain." For the most part, the US is characterized not as a selfish, self-interested, capitalist hegemon, but as a political superpower whose objectives were compatible with democracy and prosperity. The USSR, however, is pictured as a bête noir, especially under Stalin whose personality and ideology posed an unprecedented threat to the West, in particular to the US.

The series starts out in grand form. It illuminates the beginning of the first nuclear age by showing in bold relief the overpowering images of a nuclear explosion with the familiar mushroom cloud followed by some grim images of death and destruction in Hiroshima. The year 1945 is used as a convenient point of departure because it was not only the end of one of the most destructive wars but also the beginning of another much longer and more costly struggle. In the process, however, the documentary greatly simplifies our understanding of the Cold War by spending a disproportionate amount of time on 1945 and after, while making it appear as if the years from 1917 to 1945 had little to do with the final product. Out of 24 episodes, only one short part of the first episode is spent on the years from 1917 to 1945 . In fact, the episode is mistakenly entitled "Comrades, 1917-1945," a misnomer, because, for most of those years, the US and the Soviet Union were not comrades, not even during the Grand Alliance of 1941-45, which was an alliance of necessity and convenience, not one of genuine friendship. It is true that the $\mathrm{CNN}$ documentary makes references to 1917 and the Bolshevik Revolution, the exclusion of Russians from the Paris Peace Conference, and the invasion of Russia by thousands of Allied (including US) troops who were there partly to challenge the Bolshevist forces. But the seminal role played by the US in contributing to the foundation of the Cold War through its diplomacy, its anti-Bolshevik ideology, its political and economic system, and its policies is not sufficiently illuminated, examined, and stressed. ${ }^{2}$ That the US refused to recognize Russia diplomatically from 1917 to 1933 not only reflected official US hostility toward the new government and toward a new political and economic order, but also helped lay the basis for a new era of ideological division, intolerance, and misunderstanding and a new climate of domestic and international fear, repression, propaganda, and political polarization. Yet the diplomatic reality of non-recognition for sixteen years is never mentioned in the narration and only briefly discussed by George Kennan during an interview without any explanation of its profound consequences. 
Moreover, the ideological values and the political and economic objectives reflected by such official isolation and exclusion are never brought to light and examined. On the contrary, no reference is made to how President Wilson's goal of a liberal, capitalist, international order appeared threatened by what Wilson himself called the "poison of Bolshevism" or of how fearful and fanatical his political colleagues like Secretary of State Lansing, or his own closest adviser, Colonel House, were about dealing with the "spectre" of Bolshevism and the epidemic proportions they believed it assumed. ${ }^{3}$ To shed light on these characteristics is to illuminate the deep connections between the liberal, capitalist values and objectives of Americans and the deliberate pursuit of antiBolshevik politics that lay partly at the root of the Cold War. Nor is mention made of the virulent anti-communism and anti-radicalism. practiced domestically during the first so-called Red Scare from 1919 to 1920 when about 250 alleged radicals were deported and when thousands of other alleged radicals were rounded up in raids sweeping the country.

After 1920, with the defeat of the Democrats and the disillusionment of many Americans with World War I and US involvement abroad, US foreign policy, especially in Europe, changed its direction and emphasis, but its fundamental purpose and nature remained the same. CNN stresses the insular, inward-looking character of the US after World War I, pointing to a country that showed little interest in Europe or the Soviet Union until after Franklin Delano Roosevelt became President in 1933 and officially recognized the USSR. What it neglects to point out is the aggressively expansive economic and financial relations of the US with other countries throughout the world, including the USSR. For the 1920's was a decade in which the American economy and its financial investments expanded disproportionately, boding well for the US and many of its trading partners in the short run, but portentous of difficult times and grave imbalances in the world economy in the long run. ${ }^{4}$ Soviet-US relations, while often less intensely hostile during the Republicans' tenure than during Wilson's, continued on an antagonistic course. The Republican administrations extended Wilson's non-recognition policy but, at the same time, shipped food and medicine to a Russia plagued by famine and hard times, and encouraged businesses like General Electric and Ford Motor to enter the Soviet marketplace. This was symptomatic of an American capitalism so strong and expansive that it could transcend the narrow ideological confines of anti-Bolshevism. By the same token, the stock market crash of 1929 and the ensuing depression were fundamentally responsible for the precipitous decline in trade and economic relations between the US and USSR, even after F.D.R. extended recognition to the USSR. 


\section{Left History 6.1}

These overwhelming structural impediments, in conjunction with the shocking legacy of Stalinist rule in the 1930's, could not help but intensify the ever-growing anti-Bolshevist perspective of the US. This perspective could only diminish the prospects for co-operation and harmony between these allies during and after World War II. Therefore, when circumstances and pressures combined to create further antagonism at the end of World War II, this conflict would be greatly conditioned by the mutual suspicions, the ideological and economic incompatibility, and the deep sense of distrust that had already built up during the years between 1917 and 1941. It was this seminal foundation of Cold War tensions that the CNN documentary has failed to illuminate.

Similarly, the CNN series has neglected to point out the myriad ways in which the US reinforced and, at times, initiated Cold War tensions at the conclusion of and after World War II. Conspicuously absent is a critique of the West's, specifically the US's, inability and unwillingness to understand the security, geopolitical, economic and military concerns of the Soviets. In this regard, American arrogance was especially striking given the fact that the US had 434 military bases strewn throughout the world, a monopoly of the A-bomb, the world's largest navy and airforce, and a dynamically expanding economy, making it the wealthiest and most powerful nation on the planet.

Well before the end of World War II, the US made it difficult for the USSR to feel an integral part of the Grand Alliance. For the US withheld support for the second front until 1944, delayed or canceled promises of financial and military help, and refused to consult and include the Soviets genuinely as a partner in the deliberations on the post-war world. How was the USSR to behave as an ally when it was left to bear the brunt of the military losses on the western front -27 million - and was refused the financial assistance it required to begin the painful and costly task of reconstruction? The CNN series acknowledges the traumatic impact which the loss of 27 million soldiers and civilians had on the Soviet Union and its security needs, but the series neglects to clarify how this contributed to the tensions between East and West and to the makings of the post-World War II Cold War. Nor does it point out that in excluding the USSR from contributing to the deliberations on Italy during the armistice in 1943, the US and Great Britain set an ugly precedent for their own exclusion from the affairs of Eastern Europe in 1945 and thereafter.

Even more important and ominous was America's detonation of the atomic bomb just as the Potsdam conference was opening and its dropping of the Abomb on Hiroshima and Nagasaki. These actions also underscored American responsibility for the dawn and escalation of the nuclear arms race, something that would plague international relations from that point on while further 
intensifying the Cold War. Substantive evidence suggests that the motives behind the use of the bomb were related not just to ending World War II, but also to using atomic diplomacy as a powerful weapon against the Soviet Union. ${ }^{5}$ After 1945, the US had viable options other than maintaining an atomic monopoly and extending its nuclear arsenal, but the record clearly shows that, as with so many other Cold War decisions, the US rejected constructive alternatives that might have changed both the course of the arms race and that of the Cold War. Interestingly enough, the CNN producers chose yet again not to illuminate these tarnished areas of American history. Nor did this series reveal the extent to which there was still choice and malleability in the foreign and domestic affairs of the US, opportunities that might still have had an impact upon the Cold War.

In confronting what was the most contentious issue on the European continent after World War II — the future of Germany — the US clearly pursued its own economic and political interests while closing off more constructive possibilities of a modus vivendi with the Soviet Union. For when "containment" was taken to mean preventing the Soviet Union from penetrating the West while allowing it to carry on unchallenged in its own sphere of influence and when the western powers, not the USSR, made the deliberate decision to divide Germany, the US and its western allies gave up on a historically unique opportunity to create a neutral, unified nation in Europe, one that might well have changed the course of the Cold War. At the same time, alternatives to containment and to pursuing the Cold War with the USSR were conveyed by American politicians as well as journalists. Henry Wallace, for example, Secretary of Commerce for a short time in the early Truman administration, offered a more conciliatory approach to the USSR, while journalists like Walter Lippmann and, later on, I.F. Stone remained critical of the hard and inflexible course pursued by Truman and Eisenhower. Wallace paid for his criticism by being fired from his position, but he eventually ran for President as leader of the newly formed Progressive Party - a challenge not only to the Cold War consensus, but also to the two party system. Even though these critics were at first not successful, they persisted in their criticism which eventually helped shatter the Cold War consensus.

Although very different political, economic, and social forces existed in Southeast Asia from those in central and eastern Europe, there can be no doubt about the fact that the course and outcome of the Cold War was not just contingent upon the communists in China, Korea, and Vietnam, but also dependent upon the policies and actions of the US. The efforts of Mao Tse Tung and Chou En Lai to communicate constructively with the US Government while the Chinese revolution was still raging, and to create an alternative to the 
entrenched and predictable policy responses of the US vis-à-vis the Nationalists and the Communists, fell on deaf ears and blind eyes; they did suggest the potential for a modus vivendi between China and the US that might well have changed the dynamics of conflict and of the Cold War on that continent with a more accommodating and progressive response from the US. ${ }^{6}$ And the possibilities that existed between Ho Chi Minh and F.D.R. at a time when the US was critical of French colonial rule and had sympathetic leanings in the direction of the Vietminh also reveal the wide parameters within which relationships could still be fluid, flexible and accommodating. ${ }^{7}$ That all of this crystallized and ossified in a few years was not just a reflection of the intensification of the Cold War along East-West lines but was also symptomatic of profound social and economic upheaval and various struggles of national liberation in the third world that were exacerbated by US intervention. Once American predilections and imperatives dictated an unprecedented leap toward militarization, as was evidenced by the Korean War, NSC-68, and the quadrupling of the American defense budget, the so-called die was cast, and it would be difficult from that point forward to escape the structural conditions that accompanied the rigorous prosecution of Cold War policy.

In the world of CNN, however, little of this complex historical reality is conveyed. This is so not only because this overly ambitious but simplistic documentary spends far too little time dissecting the Chinese Revolution, the Korean War, and especially the War in Vietnam as struggles between peasant revolutionaries and colonial/imperialist elites rather than simply as a function of East-West, Cold War tension but also because its packaging of history does not reflect the historical controversies of past debates which brought to light much in American history still hidden from public view. To correct this structural flaw requires in part a wider, more comprehensive consultative process, involving the active participation of a number of revisionists as well as more traditional historians at every stage of production. But it also necessitates a willingness and a determination to dispense with political orthodoxy and conventional history and to illuminate historical truths by unraveling the historical controversies and findings of past and current debates. To do this might also involve transcending our cultural, political, and economic limitations and norms so that history can no longer by hijacked by those who stress form over substance, entertainment over education, suspense over accuracy, and the politically fashionable over historical truth and criticism.

Benjamin D. Lowinsky

York University 
'Scholars belonging to the traditional school of thought include Arthur Schlesinger, Jr., Herbert Feis, Adam Ulam and Walt Rostow. Those who are known as revisionist, New Left scholars include William A. Williams, Walter LaFeber, Barton Bernstein, Lloyd Gardner, David Horowitz, Richard Barnet, Thomas McCormick, Gar Alperovitz, Thomas Paterson and Gabriel Kolko. They came to intellectual maturity during the 1960's while the war in Vietnam and the Cold War were raging, and reflected the disillusionment and radical revisionism of many members of the protest movement, known as the New Left. Their opposition to the war in Vietnam was in part founded on their fundamental critique of the U.S. contribution to the Cold War and on their criticism of the dysfunctional and reactionary nature of the U.S. economic and political system. The debate between these schools was dynamic and provocative not only because it reflected the deep cleavage of values and generations that characterized part of the tumultuous and polarizing politics of the 1960's. Since then, it has never quite been the same, for, beginning in the 1970's and continuing on through to the 1990's, scholars have grasped in vain for a "post-revisionist synthesis." But such synthesis remained elusive because it could never replace traditional and revisionist perspectives, nor did it develop a point of view fundamentally different from either traditional or revisionist perspectives.

${ }^{2}$ For some seminal works on the subject, see Arno Mayer, The Political Origins of the New Diplomacy (New Haven 1959); Arno Mayer, Politics and Diplomacy of Peacemaking (New York 1967); N. Gordon Levin, Woodrow Wilson and World Politics (New York 1968); John M. Thompson, Russia, Bolshevism, and the Versaille Peace (Princeton 1966).

${ }^{3}$ See Levin, op. cit.; Mayer, Politics and Diplomacy of Peacemaking (New York 1967); Ray S. Baker, Life and Letters (New York 1939), vol. 8, 464-65; David F. Houston, Eight Years with Wilson's Cabinet, vol. 1 (Garden City, N.Y. 1926), 320-21; Charles Seymour, ed., The Intimate Papers of Colonel House (Boston 1928), vol. 4, 118-19; E. David Cronon, ed., The Cabinet Diaries of Josephus Daniels, 1913-21 (Lincoln, Nb. 1961), 342; Herbert Hoover, The Ordeal of Woodrow Wilson (New York 1958), 1977).

${ }^{4}$ See William A. Williams, "The Legend of Isolationism in the 1920's" Science and Society, 18 (1954), 1-20; William A. Williams, The Tragedy of American Diplomacy (New York [1959], 1962); Joan Hoff Wilson, American Business and Foreign Policy, 1920-33 (Lexington, Mass. 1971); Stephen V.O. Clarke, Central Bank Cooperation: 1924-31 (New York 1967); Melvyn P. Leffler, The Elusive Quest (Chapel Hill 1979); Frank Colstigliola, Awkward Dominion (Ithaca, N.Y. 1984).

${ }^{5}$ See Gar Alperovitz, Atomic Diplomacy: Hiroshima and Potsdam, rev. edition (New York 1985); Gar Alperovitz, The American Decision to Use the Bomb (New York 1995); Martin Sherwin, A World Destroyed (New York [1973], 1987); Gregg Herken, The Winning Weapon (New York 1980); Robert Jay Lifton and Greg Mitchell, Hiroshima in America: A Half Century of Denial (New York 1995).

6 See Barbara Tuchman, "If Mao had Come to Washington: An Essay in Alternatives," Foreign Affairs, 51 (1972), 44-64; Nancy Bernhopf Tucker, "China and America, 19411991," Foreign Affairs, 70 (Winter 1991-92), 75-81.

'See Robert J. McMahon, "The Cold War Comes to Southeast Asia," in Robert J. McMahon and Thomas G. Paterson, eds., The Origins of the Cold War, 4th ed. (Boston, 1999); George C. Herring, America's Longest War, 3rd ed. (New York 1996), 9. 